Supposing no grass at all to exist, the rate of erosion will be still more rapid, as on the recent volcanic cones mentioned above, or as may be seen on a new railway embankment or cutting where one or two years' storms produce perfect models of mountain glens and ravines in miniature.

J. Beete Jukes.

DUBirs, April 6th, 1866.

ORIGIN. OF VALLEYS.

To the Editor of the Grologicad Magazine.

Srr,-As I have commenced a line of investigation among tho valleys, gorges, and drifts of Central Wales, which will require for its completion a series of observations on the sea-coast of Cardiganshire, I shall not take up your valuable space with a concluding article on the Origin of Valleys for several months to come. Meantime permit me to add a few lines to my last article. ${ }^{1}$ The combes behind Malvern Wells are much deeper than they would seem from the woodcut on page 157. The one behind the Holy Well (right side of the woodcut) embraces nearly three-fourths of a circle, and is exceedingly smooth and regular in its outline. All the three combes referred to have been cut back beyond the axial ridge of the Malverns. The rocks in which they have been scooped out would, by Dr. Holl, be classified as Hornblendic and Micaceous Gneiss, with Quartzo-Felspathic and Granitic veins. In reference to the denudation of the Longmynd Valleys, locally called "gutters," Mr. R. Wilding, of Church Stretton, reminds me of a cwm (English combe) to the north of Carding Mill valley, with no regular stream flowing through it; and this cwm must have been excavated by the same cause as that to which the valleys owe their origin. Mr. Wilding is convinced that the streams have only furrowed the bottoms of the valleys of the Longmynd.

I now write from the heart of Siluria; and on entering this hallowed region, I was struck with its richness, not only in underground relics of the past, but in the most striking indications of the various modes in which the surface of the earth has been denuded. This is the land, not only of trilobites, but of escarpments, cliffs, cwms, gorges, and all kinds of drifts. Geological tourists, during the coming season, would do well to devote particular attention to the stupendous accumulations of tumultuously-distributed clay, earth, and sand, with enormous rounded boulders, which may now be seen exposed in cuttings on the line of railway running between Hereford and Llanidloes. The successive tiers of inland sea-cliffs, half wrecked by the weather, but still retaining in sheltered situations their smoothed, grooved, pitted, and caverned forms, near Abereddw, are likewise worthy of minute inspection. Neither ought the tourist to pass by the deep and rocky ravines of the "Great Desert" of Central Wales, to the west and south of Rhyader.-Yours truly,
ButLth, Brbconshirg.
D. M.ckintosh.

1 GroL. MAG., April, 1866. At page 166, line 25, for "indication," read "induction." 
P.S.-There is here a small geological class, the members of which take the "Geological Magazine," and read "The Silurian System." I have just re-perused (after a lapse of many years) the chapters on Drift at the close of Sir R. I. Murchison's celebrated work; and I cannot help thinking that the accurate descriptions and sound generalizations with which they abound, if re-published separately, would be of great service in moderating the zeal of modern subaërialists. I see Sir Roderick accounts for combes in the same way that I have lately been advocating in your pages. He says "These combes and valleys could have been modelled into their actual forms only by the action of a large body of water overspreading their entire area. . . . The nature of the excavation indicates also the action of water differently propelled at different times, perhaps by tidal currents, the directions of which were determined by local causes."-D.M.

\section{THE ORIGIN OF BITUMEN,}

\section{To the Editor of the Geological Magazing.}

SrR,-Y Your issue for March contains an article on "Petroleum and Oilfields," in which my views on the generation of bituminous substances are alluded to and controverted; at the same time a desire is expressed for further information respecting the occurrence of petroleum and bitumen in Trinidad.

If "E. C. H. D.," author of the article in question, had carefully considered the evidence adduced in the "Report on the Geology of Trinidad," he could scarcely have arrived at the conclusion that the direct production of bitumen from vegetable remains is doubtful, or the proofs of the production " defective," since this view is not proposed as a theory, but stated as an evident fact, beyond the range of discussion.

To detail, briefly as possible, the proofs on which this origin of bitumens is founded, viz.:- the existence over the bituminous districts of strata more or less charged with vegetable debris, with the woody matter in progress of conversion into bitumen, which conversion is induced entirely by internal chemical action, and independent of any extraneous influence, such as heat. This process is distinguished by the production of a dense, very black petroleum, which oozes out of the vegetable mass and only ceases to be formed on the complete change of the woody substance into bitumen; and is also accompanied by the formation of hydro-carbons. This oily fluid gradually solidifies (probably from the evaporation of a volatile solvent), leaving a black, very pure bitumen, locally known as "glance pitch." The residue of the wood is represented by a brownish black bitumen of impurer nature, in which all trace of vegetable structure has disappeared. The operation of this conversion is so intense, that hand specimens of the wood, when isolated from their earthy matrix and placed in a room, have continued to 